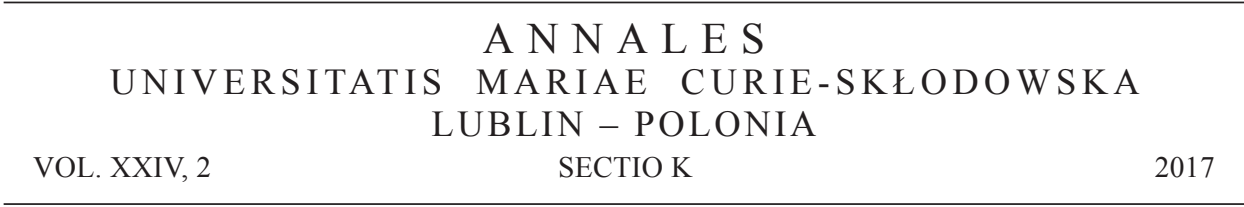

Instytut Historii i Nauk Politycznych Uniwersytetu w Białymstoku

EWELINA WAŚKO-OWSIEJCZUK

\title{
Hard power versus soft power - zmiana polityki zagranicznej USA z ofensywnej na defensywna za rządów Baracka Obamy
}

\author{
Hard Power Versus Soft Power - a Change of US Foreign Policy from Offensive to Defensive \\ under the Leadership of Barack Obama
}

\begin{abstract}
ABSTRAKT
Prezydencką kampanię wyborczą w 2008 r. zdominowały dwie kwestie - polityka zagraniczna i rosnący deficyt budżetowy. Zapowiedź Baracka Obamy o całkowitym odwrocie od agresywnej polityki poprzednika okazała się skuteczną taktyką, umożliwiającą mu wygranie wyborów prezydenckich. Od tej pory supermocarstwo zamiast siły militarnej miało wykorzystywać dialog i dyplomację. Odnowienie wizerunku USA na świecie wymagało od prezydenta Obamy odejścia od polityki zagranicznej opartej na hard power, samodzielnych, prewencyjnych i jednostronnych działaniach, na rzecz bliskiej współpracy $\mathrm{z}$ innymi uczestnikami stosunków międzynarodowych.
\end{abstract}

Słowa kluczowe: bezpieczeństwo, polityka zagraniczna, Stany Zjednoczone Ameryki, Barack Obama, George W. Bush

\section{WSTĘP}

Kiedy w 2008 r. Barack Obama wygrał wybory, media przedstawiały przyszłego prezydenta USA jako „Kennedy’ego swojej generacji”, ucieleśnienie „amerykańskiego snu” [Marschall 2008] czy ,pragmatycznego idealistę" [Zaborowski 2013: viii-ix]. Obama jawił się jako całkowite przeciwieństwo George'a W. Busha - przeciwnik wojny w Iraku i stosowania tortur wobec podejrzanych o terroryzm ${ }^{1}$, zwolennik

1 Za rządów administracji George’a W. Busha Centralna Agencja Wywiadowcza (CIA) została wyposażona w wiele narzędzi, mających ułatwić agencji misję ścigania terrorystów. Osoby podejrzane 
zamknięcia więzienia w Guantanamo², propagator dialogu i konsensusu. W swoich planach miał zakończenie porozpoczynanych przez poprzednika wojen, uspokojenie świata, sprowadzenie amerykańskich żołnierzy do domu, odbudowanie nadszarpniętych relacji z innymi państwami, zmianę wizerunku supermocarstwa z „bandyckiej potęgi” [Garrison 2005: 9] na „łagodnego hegemona” [Miller 2014: 235].

Celem niniejszego artykułu jest analiza głównych założeń doktryny Busha i Obamy. Autorce zależało na pokazaniu nie tylko różnic i podobieństw w sferze koncepcyjnej, lecz także praktycznych przejawów realizacji dwóch doktryn, co ma potwierdzić postawioną w tytule artykułu tezę, iż za rządów Baracka Obamy doszło do zmiany polityki zagranicznej USA z ofensywnej na defensywną. Głównym narzędziem do jej realizacji stała się koncepcja soft power, którą należy rozumieć jako „zdolność uzyskiwania tego, czego się chce, raczej dzięki atrakcyjności niż przymusowi. Jest ona rezultatem atrakcyjności kultury i politycznych ideałów" [Nye 2007: 11; zob. również Włodkowska-Bagan 2012: 36 i n.]. Warto zaznaczyć przy tym, że wykorzystywanie soft power $\mathrm{w}$ polityce zagranicznej nie jest oznaką słabości, a raczej siły. $\mathrm{W}$ tym znaczeniu wymuszenie decyzji czy działań przy pomocy siły militarnej jest mniej skuteczne niż zaangażowanie się stron $\mathrm{w}$ dane działania, co znacząco może wpłynąć na ich efektywność. Przeciwieństwem miękkiej siły jest hard power, która wiąże się z wykorzystaniem środków przymusu, zwłaszcza militarnych, podczas realizacji polityki zagranicznej państwa [Nye 2007: 9; zob. również Włodkowska 2010: 59 i n.]. Innym pojęciem wymagającym wyjaśnienia jest doktryna, którą autorka rozumie jako koncepcję polityki zagranicznej państwa. Zarówno doktryna G.W. Busha, jak i B. Obamy znalazła swój wyraz w dokumentach strategicznych, które zostaną poddane analizie w niniejszym artykule. Obok krytyki i analizy źródeł autorka wykorzystała metodę porównawczą, która była szczególnie przydatna podczas zestawienia założeń obydwu doktryn oraz realizacji polityki zagranicznej administracji G.W. Busha i B. Obamy.

\section{DOKTRYNA WOJNY PREWENCYJNEJ}

Powstała w wyniku zamachów z 11 września 2001 r. atmosfera strachu ułatwiła wprowadzenie zmian w polityce zagranicznej USA, która przybrała charakter ofensywny. Administracja George'a W. Busha miała przyzwolenie zarówno środowiska międzynarodowego, które uznało prawo USA do samoobrony ${ }^{3}$, jak i Kongresu, uzyskując zgodę na użycie wojsk poza terytorium kraju [President

\footnotetext{
o prowadzenie działalności terrorystycznej były poddawane tzw. wzmocnionym technikom przesłuchan, które dopuszczały m.in. podtapianie [Isikoff 2009].

2 Amerykańska baza wojskowa w Guantanamo, którą za rządów G.W. Busha przekształcono w więzienie dla osób podejrzanych o terroryzm, stała się niechlubnym symbolem wojny z terroryzmem [Myers 2008; Waśko-Owsiejczuk 2016b].

3 Amerykanie mogli liczyć na wsparcie organizacji międzynarodowych, licznych państw zarówno świata zachodniego, jak i arabskiego [Waśko-Owsiejczuk 2014: 146].
} 
Signs Authorization for Use of Military Force bill 2001]. Wraz z zamachami na World Trade Center i Pentagon szansę na wprowadzenie swoich założeń w życie zobaczyli neokonserwatyści, którzy po wyborach w 2000 r. znaleźli się w gronie bliskich współpracowników prezydenta Busha juniora ${ }^{4}$. Już podczas I wojny w Zatoce Perskiej apelowali do prezydenta Busha seniora o obalenie rządów Saddama Husajna w Iraku [Szymborski 2004: 67]. Plany inwazji czekały blisko 13 lat na realizację. Neokonserwatyści jako zwolennicy stosowania hard power w polityce zagranicznej, obok obalenia totalitarnych reżimów, głosili hasła zdecydowanej obrony interesów narodowych Amerykanów, wzmocnienia przywództwa USA na świecie oraz zwiększenia wydatków na cele zbrojne, co miało wzmocnić potęgę supermocarstwa [Zając 2008: 49].

Założenia i poglądy neokonserwatystów w wielu punktach były spójne z doktryną G.W. Busha, którą oficjalnie ogłoszono we wrześniu 2002 r. w dokumencie National Security Strategy of the United States of America - NSS, np. przekonanie o konieczności odgrywania aktywnej roli USA w świecie, co miało znacząco wpływać na bezpieczeństwo supermocarstwa, ochronę narodowych interesów Amerykanów za granicą i zapewnić porządek międzynarodowy. W tym celu należało utrzymać potęgę militarną supermocarstwa, która $\mathrm{z}$ jednej strony miała odstraszać potencjalnych wrogów, z drugiej zaś umożliwić szybką i zdecydowaną reakcję na pojawiające się nagle zagrożenia. Zarówno neokonserwatyści, jak i G.W. Bush wychodzili z założenia, że potęga i wyjątkowość amerykańska predestynuje USA do pełnienia roli przywódcy na świecie. Za cechę wspólną należy uznać również podejście unilateralne do stosunków międzynarodowych. W tym znaczeniu decyzje i działania Stanów Zjednoczonych Ameryki nie powinny być ograniczane przez instytucje i umowy międzynarodowe. G.W. Bush zgadzał się również z jednym $z$ nadrzędnych poglądów neokonserwatystó $w^{5}$ o potrzebie obalenia dyktatorskich reżimów, szerzenia demokracji i praw człowieka na świecie. Jego doktryna opierała się na założeniu, że Stany Zjednoczone Ameryki jako jedyne supermocarstwo mają prawo, a nawet obowiązek prowadzić działania unilateralne i prewencyjne. To Amerykanie mieli decydować, gdzie będą interweniować, kto im będzie towarzyszył i jakich środków będą używać podczas misji szerzenia uniwersalnych (amerykańskich) wartości na świecie. Najwięcej kontrowersji wzbudził fragment NSS z 2002 r. mówiący o tym, że w razie zagrożenia Amerykanie nie zawahają się skorzystać z prawa do samoobrony przez uprzedzające uderzenie [The National Security Strategy of the United States of America 2002].

Kwintesencja doktryny G.W. Busha, a więc samozwańcze przyznanie sobie prawa do prowadzenia działań prewencyjnych i unilateralnych, ujrzało światło dzienne

${ }^{4}$ W administracji Busha do grona neokonserwatystów należeli m.in.: Paul Wolfowitz (zastępca sekretarza obrony), Robert Kagan (doradca prezydenta i sekretarza stanu), I. Lewis Libby (asystent prezydenta i szef kancelarii wiceprezydenta), Richard Perle (asystent sekretarza obrony ds. polityki bezpieczeństwa), Douglas Feith (podsekretarz ds. polityki obronnej) [Zając 2008: 49].

5 Główne filary neokonserwatyzmu [Vaïsse 2010: 3-6]. 
już w 1992 r. za sprawą Paula Wolfowitza i Dicka Cheneya, których poglądy zawarto w raporcie Defense Planning Guidance. Dokument opublikowano na łamach „New York Timesa”, wywołując jednocześnie gorącą dyskusję [Tyler 1992]. W raporcie przedstawiono najważniejsze zadania i wytyczne strategii obronnej USA na lata 1994-1999. Począwszy od konieczności podjęcia działań uniemożliwiających pojawienie się konkurencyjnego mocarstwa w Europie Zachodniej, Azji czy na terytorium byłego ZSRR, przez zwiększenie wydatków na cele obronne USA, pełnienie roli przywódcy i propagatora demokracji oraz wolności na świecie, aż po gotowość supermocarstwa do podejmowania działań prewencyjnych i niezależnych [Defense Planning Guidance 1992]. Niezrealizowane za rządów Busha seniora plany neokonserwatyści mogli wcielić w życie podczas prezydentury jego syna.

Praktycznym przejawem realizacji doktryny Busha była interwencja zbrojna w Afganistanie (2001 r.) oraz inwazja na Irak (2003 r.). Podczas kiedy pierwsza miała wsparcie społeczności międzynarodowej oraz legalne podstawy ${ }^{6}$, to na operację militarną w Iraku nie było ani zgody Rady Bezpieczeństwa ONZ, ani faktycznych powodów wtargnięcia na teren innego suwerennego państw ${ }^{7}$, nie mówiąc już o wielomilionowych protestach antywojennych, które miały miejsce na całym świecie [Millions join global anti-war protests 2003]. Plan amerykańskiej administracji wydawał się prosty; obalamy reżim Saddama Husajna, zabezpieczamy irackie złoża ropy naftowej i rozpoczynamy proces przemian demokratycznych w Iraku, który miał rozprzestrzenić się na cały Bliski Wschód. Idealistycznie zakładano, że zainspirowana procesem przemian społeczność innych państw w regionie podąży za przykładem Irakijczyków, domagając się zmiany ustroju. W tym celu Amerykanie uruchomili programy reform politycznych, ekonomicznych i społecznych, które w większości okazały się mało skuteczne, głównie ze względu na brak zaufania rządów arabskich wobec amerykańskich planów przemian ustrojowych ${ }^{8}$. Jak nietrudno było przewidzieć, wprowadzenie siłą demokracji nie zachęciło innych narodowości do podążania ścieżką Irakijczyków. Efekt był całkowicie odwrotny od

6 Już 11 września 2001 r. NATO odwołało się po raz pierwszy w swej historii do art. V traktatu waszyngtońskiego, będącego jednocześnie maksymą organizacji: ,jeden za wszystkich, wszyscy za jednego”, który oznacza, że w przypadku ataku na jedno z państw sojuszniczych pozostali członkowie występują w jego obronie. Operację w Afganistanie przeprowadzono zgodnie z art. 51 Karty Narodów Zjednoczonych, który przyznaje państwom prawo do samoobrony oraz w oparciu o rezolucję Rady Bezpieczeństwa ONZ nr 1368 (2001) z 12 września 2001 r. Amerykanom udało się zbudować międzynarodową koalicję antyterrorystyczną, w której znalazły się państwa oferujące różne formy pomocy - od dostarczania informacji, po zaangażowanie zbrojne [Modrzejewska-Leśniewska 2010: 436 i n.].

7 Wśród deklarowanych powodów inwazji na Irak administracja G.W. Busha wymieniła posiadanie broni masowego rażenia przez reżim Saddama Husajna, koneksje dyktatora z Al-Kaidą, chęć wyzwolenia narodu spod ucisku tyrana i zaprowadzenie demokracji na Bliskim Wschodzie [Waśko-Owsiejczuk 2014: 209 i n.].

8 Rządy państw arabskich chętniej akceptowały programy ekonomiczne, które zapewniały im wsparcie finansowe. Z ogromną nieufnością i sceptycyzmem podchodzono natomiast do planów reform społecznych i politycznych, ponieważ obawiano się, że ograniczą bądź całkowicie obalą ich władzę [Waśko-Owsiejczuk 2015: 21-35]. 
zamierzonego, ponieważ wzrosła nieufność i pojawiły się nastroje antyamerykańskie w regionie, które jeszcze bardziej pogłębiły się po ujawnieniu informacji o torturowaniu przez Amerykanów więźniów osadzonych w Abu Ghraib ${ }^{9}$ czy wykorzystaniu białego fosforu jako broni podczas bitwy o Faludżę ${ }^{10}$.

Podczas drugiej kadencji G.W. Busha jego współpracownicy podjęli starania naprawy nadszarpniętych po inwazji na Irak relacji z innymi państwami oraz odbudowy nadwyrężonego wizerunku ,ppolicjanta świata”. Nie było to łatwe zadanie, ponieważ USA zarzucano hipokryzję - oto strażnik praworządności i propagator poszanowania praw człowieka na świecie, sam dopuścił się stosowania tortur i łamania prawa. Nagle hasła o wyjątkowości Ameryki, uniwersalnych wartościach straciły na znaczeniu, tym bardziej że administracja Busha poza podjęciem wysiłków dyplomatycznych, które przejawiały się w licznych podróżach prezydenta i jego współpracowników zwłaszcza do Europy, żeby pokazać otwartość na dialog, w sferze koncepcyjnej nie uległy zmianie. Kwintesencja założeń polityki prezydenta Busha, a więc prawo do prowadzenia działań prewencyjnych i unilateralnych, znalazło swoje potwierdzenie w kolejnej Strategii Bezpieczeństwa Narodowego z 2006 r. ${ }^{11}$ Tym samym prezydent supermocarstwa potwierdził zamiar kontynuowania obranego kursu polityki, odmawiając m.in. wydania decyzji o opuszczeniu Iraku przez wojska amerykańskie niemal do końca drugiej kadencji ${ }^{12}$. Administracji Busha zależało na zmianie wizerunku, ale nie polityki, tym bardziej że coraz usilniej zabiegano o podzielenie się ciężarem odpowiedzialności za wojnę w Iraku z innymi uczestnikami stosunków międzynarodowych. Amerykanie nadal mieli przewodzić całej misji stabilizacyjnej, jednak ze względu na ogromne koszty działań, straty w ludziach i pogarszający się stan bezpieczeństwa apelowali o wsparcie m.in. Organizacji Narodów Zjednoczonych. Obok pomocy humanitarnej członkowie

${ }^{9}$ Z informacji ujawnionych w maju 2004 r. przez amerykańskiego dziennikarza Seymoura Hersha na łamach magazynu „New Yorker” wynika, że w okresie od października do grudnia 2003 r. w więzieniu Abu Ghraib wobec zatrzymanych miały miejsce liczne przypadki sadystycznych, rażących i samowolnych kryminalnych nadużyć ze strony Amerykanów [Hersh 2004].

${ }^{10}$ Chociaż początkowo administracja Busha zaprzeczała, to ostatecznie Amerykanie przyznali się do wykorzystywania białego fosforu jako broni w 2004 r. podczas bitwy o Faludżę [Burns 2005].

${ }_{11}$ W dokumencie powielono założenia NSS z 2002 r. W związku z tym, że USA znalazły się w stanie wojny, priorytetem było zapewnienie Amerykanom bezpieczeństwa. Supermocarstwo nadal miało przewodzić misji szerzenia na świecie demokracji, wolności i sprawiedliwości oraz położyć kres reżimom dyktatorskim. Zakładano przy tym wzmocnienie sojuszy w celu pokonania terrorystów, potwierdzając jednocześnie samowolnie nadane USA prawo do podejmowania działań prewencyjnych i unilateralnych, kiedy bezpieczeństwo supermocarstwa bądź interesy narodowe Amerykanów będą zagrożone. Zob. The National Security Strategy of The United States of America, White House 2006, http://georgewbush-whitehouse.archives.gov/nsc/nss/2006/ (dostęp: 04.03.2016).

${ }^{12}$ W listopadzie 2008 r. prezydent Bush podpisał umowę pomiędzy USA i Irakiem, w której uzgodniono datę wycofania wszystkich oddziałów wojsk amerykańskich z Iraku na 31 grudnia 2011 r. Zob. Status of Forces Agreement: Agreement Between the United States of America and Republic of Iraq On the Withdrawal of United States Forces from Iraq and the Organization of Their Activities during Their Temporary Presence in Iraq, Baghdad 2008, http://www.state.gov/documents/organization/122074.pdf (dostęp: 04.03.2016). 
ONZ mieli wysłać wojska w celu utrzymania pokoju oraz wesprzeć finansowo odbudowę Iraku ${ }^{13}$.

Amerykanie popełnili w Iraku wiele błędów - pierwszym była sama inwazja, jednak kolejne decyzje pogłębiły tylko kryzys. Jedną z katastrofalnych i chyba nieprzemyślanych decyzji była likwidacja armii irackiej, której skutkiem było pozostawienie bez pracy i środków do życia ponad 300 tysięcy sfrustrowanych mężczyzn, wyposażonych w broń i opancerzone samochody [Tanner 2007: 251]. Nietrudno było przewidzieć następstwa tej decyzji. Wielu z nich znalazło się w szeregach grup terrorystycznych i przystąpiło do walki ze światem zachodnim. Jak się okazało, pochopna decyzja G.W. Busha o inwazji na Irak doprowadziła do stworzenia innego wymiaru zagrożenia terrorystycznego w postaci „Państwa Islamskiego” [Waśko-Owsiejczuk 2017]. Nie jest przypadkowe to, że wśród przywódców organizacji znaleźli się byli wojskowi z armii Husajna [Creamer 2014]. Chociaż pod koniec drugiej kadencji Busha udało się w miarę opanować sytuację z terrorystami - spadła liczba zamachów w Iraku [President Bush and Iraq Prime Minister Maliki Sign the Strategic Framework Agreement and Security Agreement 2008], to warto podkreślić, że rozwiązano (jak się okazało tymczasowo) problem, który w pierwszej kolejności stworzyli sami Amerykanie. Jak słusznie wskazał Marek Dziekan, za czasów reżimu policyjnego Husajna terroryzm w Iraku był zjawiskiem nieznanym [Dziekan 2014].

Doktryna G.W. Busha miała również ogromne konsekwencje dla systemu bezpieczeństwa międzynarodowego. Bezpodstawne wkroczenie najsilniejszego supermocarstwa na teren innego suwerennego państwa przyczyniło się do destabilizacji całego systemu [Waśko-Owsiejczuk 2014: 255 i n.]. Skoro „policjant świata” sam łamie prawo międzynarodowe, dokonuje inwazji, nie ponosząc przy tym żadnych konsekwencji, to co powstrzyma inne narody przed agresywnymi działaniami. W systemie globalnego bezpieczeństwa nie może być tak, że agresja jednego z państw jest postrzegana jako misja szerzenia demokracji i praworządności, a drugiego jako bezprawne działania. Interpretacja prawa międzynarodowego w tej kwestii nie powinna być dowolna, a członkowie organizacji międzynarodowych muszą reagować tak samo na złamanie prawa bez względu na to, kto będzie agresorem. W przeciwnym razie system zbiorowego bezpieczeństwa się załamie.

\section{DOKTRYNA STRATEGICZNEJ CIERPLIWOŚCI}

W nowym prezydencie USA pokładano olbrzymie nadzieje i oczekiwania. Cała kampania wyborcza Baracka Obamy w $2008 \mathrm{r}$. była prowadzona pod hasłem change [Lizza 2008], co miało oznaczać, że wybór Obamy będzie odejściem od agresyw-

\footnotetext{
${ }^{13}$ Niemal od samego początku inwazji prezydent Bush nawoływał do zwiększenia roli i wsparcia ONZ podczas misji stabilizacyjnej, apelował o międzynarodową pomoc w celu rozwiązania problemów bezpieczeństwa Iraku. Zob. Statement by His Excellency Mr. George W. Bush, President of the United States
} 
nej polityki Busha na rzecz współpracy międzynarodowej. Nowy prezydent miał zakończyć wojnę w Iraku, zaprowadzić pokój na Bliskim Wschodzie, wyprowadzić gospodarkę amerykańską z największej od czasów Wielkiego Kryzysu recesji, odbudować nadszarpnięty wizerunek USA i przyjazne relacje z innymi państwami. Formą motywacji, czy też bardziej presji międzynarodowej było m.in. przyznanie B. Obamie Pokojowej Nagrody Nobla zaledwie dziewięć miesięcy po objęciu urzędu ${ }^{14}$.

Podstawowe założenia doktryny B. Obamy znalazły wyraz w Strategii Bezpieczeństwa Narodowego z 2010 r. (NSS), w której prezydent podkreślił, iż bezpieczeństwo supermocarstwa nie może się opierać wyłącznie na sile militarnej. Polityka zagraniczna USA miała być prowadzona w oparciu o soft power, wykorzystując środki dyplomatyczne do rozwiązywania sporów i problemów międzynarodowych. Bezpieczeństwo Stanom Zjednoczonym Ameryki miała zapewnić działalność dyplomatów w każdym zakątku na świecie, pomoc ekspertów w procesach demokratycznych, dbałość o egzekwowanie prawa, wzmocnienie systemu sprawiedliwości oraz ścisła współpraca z innymi państwami. Biorąc pod uwagę koszty zaangażowania Amerykanów w dwie wojny, które według doniesień prasowych mogły sięgać nawet od 4 do 6 bilionów dolarów [Londoño 2013], prezydent Obama podkreślił, że ciężar zapewnienia bezpieczeństwa międzynarodowego nie może spoczywać wyłącznie na USA. Wychodząc z założenia, że współpraca międzynarodowa jest kluczowa dla bezpieczeństwa supermocarstwa, od tej pory Amerykanie mieli unikać działań wojskowych w pojedynkę. Jednym z priorytetów polityki zagranicznej USA była poprawa relacji i wzmocnienie więzi ze „starymi” sojusznikami przez wspieranie m.in. modernizacji ich sił zbrojnych. B. Obama postawił dyplomacji amerykańskiej ambitny cel w postaci zbudowania nowych i głębokich relacji z państwami w każdym regionie świata. Podkreślono potrzebę pogłębienia partnerstwa z innymi ważnymi ośrodkami wpływu. Obok Chin, Indii i Rosji w dokumencie wymieniono Brazylię, Republikę Południowej Afryki i Indonezję. Wzmocnieniu miały ulec również instytucje i stosunki międzynarodowe. Dbałość o porządek międzynarodowy oparty na prawach i obowiązkach miała umożliwić rozwiązanie problemów i zagrożeń w postaci rozprzestrzeniającego się groźnego ekstremizmu, proliferacji broni masowego rażenia, zmian klimatycznych, spowolnionego globalnego wzrostu gospodarczego, konfliktów regionalnych. Podobnie jak G.W. Bush prezydent B. Obama również w NSS odniósł się do kwestii wartości amerykańskich z tym wyjątkiem, że za najwyższą uznał zobowiązanie Amerykanów do przestrzegania zasad prawa [The National Security Strategy 2010].

Jak słusznie zauważyła Aleksandra Gasztold, zarówno G.W. Bush, jak i B. Obama postawili sobie za cel „odstraszanie przeciwników, uspokojenie opinii publicznej oraz zdobycie poparcia dla ich polityki w kraju i zagranicą" [Gasztold 2017: 171]. Za

\footnotetext{
of America Address to the United Nations General Assembly, 2003, http://www.un.org/webcast/ga/58/statements/usaeng030923.htm (dostęp: 05.03.2016).

${ }^{14}$ Warto dodać, że kandydaturę Baracka Obamy zgłoszono zaledwie 12 dni po zaprzysiężeniu na prezydenta USA [Erlanger, Stolberg 2009].
} 
punkt wspólny obydwu doktryn można uznać również podejście do demokracji, jako czynnika hamującego agresję i bezprawie, z tą różnicą, że Obama uważał wzorcowe przestrzeganie przez Amerykanów prawa wewnętrznego i zewnętrznego za skuteczniejszą metodę rozprzestrzeniania ustroju demokratycznego i wolności na świecie niż zewnętrzne interwencje [The National Security Strategy 2010: 36]. Bush z kolei preferował aktywne działania, opowiadając się za walką z terrorystami i tyranami. Co więcej, zdaniem byłego prezydenta, nowy charakter zagrożenia ze strony nieprzewidywalnych terrorystów wymagał od supermocarstwa wykorzystania wszystkich możliwych środków i zdecydowanych działań [The National Security Strategy 2002: 1]. W praktyce oznaczało to sięgnięcie nie tylko do siły militarnej, lecz także wybiórcze przestrzeganie prawa ${ }^{15}$. Obama wychodził z odmiennego założenia, wskazując, iż bez względu na sytuację, wyzwania i zagrożenia dla bezpieczeństwa działania USA miały być prowadzone zgodnie z konstytucją i zasadą check and balance ${ }^{16}$.

Obaj prezydenci widzieli USA w roli przywódcy świata, z tą tylko różnicą, że B. Obama odrzucił główną maksymę doktryny G.W. Busha, czyli podejście prewencyjne w polityce zagranicznej USA [The National Security Strategy 2010: 2-3]. Administracja Obamy, zdając sobie sprawę z nadwyrężonego po rządach poprzednika wizerunku supermocarstwa na świecie, w Strategii Bezpieczeństwa Narodowego z 2010 r. położyła nacisk na odnowienie amerykańskiego przywództwa w perspektywie długoterminowej. Stany Zjednoczone Ameryki miały promować swoje wartości przez wzorcowe stosowanie się do nich. Dzięki temu chcieli odzyskać utraconą wiarygodność w szerzeniu demokracji, praw człowieka i praworządności. Kategorycznie odrzucono tortury, jako sprzeczne z amerykańskimi wartościami i prawem. Pomimo wad zinstytucjonalizowanego systemu zbiorowego bezpieczeństwa B. Obama uznał odejście od tej formy współpracy za destrukcyjne zarówno dla bezpieczeństwa USA, jak i całego świata. Tym samym optował za zwiększeniem zaangażowania supermocarstwa we wzmocnienie instytucji międzynarodowych i działania zbiorowe na rzecz wspólnych interesów. Od tej pory wszystkie państwa, które zdecydują, że chcą być częścią systemu, będą zobowiązane do przestrzeganie reguł, za których łamanie miały grozić konsekwencje. Stany Zjednoczone Ameryki miały być wzorem do naśladowania dla innych uczestników stosunków międzynarodowych [Separation of Powers and Checks and Balances].

Barack Obama nie odrzucał środków militarnych jako narzędzia realizacji polityki zagranicznej USA. Jednak wykorzystanie siły miało być ostatecznością, a nie

${ }^{15}$ Prezydent Bush wyłączył m.in. osoby podejrzane o terroryzm spod obowiązywania III konwencji genewskiej. Zatrzymani byli ponadto sądzeni nie przez niezawisłe sądy, ale przez komisje wojskowe [Roach 2011: 198 i n.]; Memorandum to Congress on President Bush's Order Establishing Military Tribunals, „American Civil Liberties Union” 2002, www.aclu.org/technology-and-liberty/memorandum-congress -president-bushs-order-establishing-military-tribunals (dostęp: 06.03.2016).

${ }^{16}$ Zasada kontroli i równowagi, która ma nie dopuścić do nadużyć władzy wykonawczej, ustawodawczej i sądowniczej. Szerzej zob.: Separation Of Powers And Checks And Balances, Cornell Law School, www.law.cornell.edu/anncon/html/art1 frag1_user.html (dostęp: 06.03.2016). 
jak w przypadku doktryny Busha - środkiem prewencyjnym. W NSS z 2010 r. wyraźnie zaznaczono, że do użycia siły militarnej może dojść w przypadku obrony kraju i sojuszników USA oraz zaistnienia zagrożenia dla bezpieczeństwa i pokoju na świecie. Podkreślono przy tym, że sięgając do siły militarnej, Amerykanie będą równocześnie zabiegać o poparcie zarówno NATO, jak i Rady Bezpieczeństwa ONZ. Za cechę wspólną obydwu doktryn można uznać przyznanie sobie prawa do prowadzenia działań jednostronnych, w sytuacji kiedy Amerykanie są zmuszeni do obrony obywateli i interesów narodowych. Z tą różnicą, że w NSS z 2010 r. zobowiązano się do przestrzegania norm regulujących użycie siły, dążąc do wzmocnienia podmiotów działających zgodnie ze standardami międzynarodowymi oraz izolacji i osłabienia tych, którzy tego nie robią [Separation of Powers and Checks and Balances: 22]. Doktryna B. Obamy różni się znacząco w treści i przesłaniu od doktryny G.W. Busha. U poprzedniego prezydenta akcent położono na wojnę z terroryzmem, zarówno w NSS z 2002, jak i 2006 r. podkreślano, że Amerykanie znaleźli się w stanie wojny, tym samym należy podjąć wszystkie możliwe środki, żeby się bronić. Doktryna B. Obamy z 2010 r. miała bardzo wyważony charakter. W dokumencie zagrożenie terrorystyczne nie było dominujące, wymieniono je jako jedno z wielu. Kluczem do rozwiązania problemów międzynarodowych miała być zinstytucjonalizowana współpraca międzynarodowa opierająca się na regułach i prawie. Stany Zjednoczone Ameryki miały stanowić wzorzec godzien naśladowania. Siła supermocarstwa miała płynąć z respektowania prawa i sojuszy międzynarodowych.

\section{HARD POWER VERSUS SOFT POWER}

Podejmując się analizy dokumentów strategicznych, należy zwrócić szczególnie uwagę na okres, w którym były tworzone, w tym na towarzyszącą mu atmosferę i nastroje społeczne. Doktryna G.W. Busha powstała tuż po zamachach $9 / 11$, kiedy Amerykanami rządziły skrajne emocje - od strachu przez rozgoryczenie, aż po chęć odwetu na sprawcach ich cierpienia. USA mogły liczyć na współczucie i solidarność zarówno świata zachodniego, jak i arabskiego. Okoliczności i nastroje społeczne stworzyły dogodny grunt pod realizację polityki zagranicznej opartej na środkach militarnych i prewencyjnych. W $2010 \mathrm{r}$. w USA panowała zupełnie inna atmosfera - odwrotu od agresywnej polityki Busha. Wprowadzenie bezwzględnego zakazu stosowania tortur oraz zapowiedź zamknięcia więzienia w bazie na Guantanamo [Separation of Powers and Checks and Balances: 21-22] miało pokazać, że USA zmieniają kurs polityki. Wówczas nie było bezpośrednich zagrożeń dla bezpieczeństwa narodowego i międzynarodowego, które wymagały pilnego rozwiązania. Tym samym nowa administracja skupiła się na odbudowie nadwerężonego wizerunku USA oraz przyjaznych stosunków z innymi państwami. Jednym z wytyczonych celów w NSS z 2010 r. była poprawa relacji na linii Waszyngton-Moskwa. Amerykanie mieli zabiegać o zbudowanie wielowymiarowej współpracy na podstawie 
wspólnych interesów. Stabilna i dostatnia Rosja była w interesie USA, które chciały współpracować z mocarstwem m.in. w zakresie ograniczania rozprzestrzeniania się broni masowego rażenia na świecie [Separation of Powers and Checks and Balances: 44]. Obok wciśnięcia przycisku reset, który symbolicznie miał oznaczać nowy etap w relacjach pomiędzy państwami [Applebaum 2009], Obama odrzucił inicjatywę Busha, która zakładała rozmieszczenie elementów systemu przeciwrakietowego w Europie Wschodniej. Decyzja ta została ostro skrytykowana, zwłaszcza przez opozycję, która zarzucała prezydentowi USA ,zdradę sojuszników i poddawanie się presji ze strony Rosji" [Baker 2009].

Przypisanie USA roli „łagodnego hegemona” wcale nie wykluczało udziału supermocarstwa w operacjach wojskowych na terenach innych państw. Zanim jednak Amerykanie zaangażowaliby się w działania militarne poza USA, musiały być spełnione trzy warunki. Po pierwsze, operacja musiałaby mieć solidne podstawy prawne. Po drugie, z założenia odchodzono od działań pojedynczych na rzecz koalicji międzynarodowych. Po trzecie, taktyka wojenna miałaby się opierać głównie na nalotach, minimalizując, jeśli nie całkowicie wykluczając, udział sił lądowych. Za przykład interwencji wojskowej realizowanej w duchu doktryny B. Obamy może posłużyć operacja amerykańskich sił powietrznych w Libii w marcu $2011 \mathrm{r}$. Zanim doszło do nalotów, interwencja została zatwierdzona przez Radę Bezpieczeństwa ONZ [Adams, Batty 2011]. Chcąc ograniczyć ryzyko strat po stronie Amerykanów, prezydent wykluczył udział sił lądowych. Zapowiedział ponadto jak najszybsze przeniesienie odpowiedzialności za operację na sojuszników. Miało to miejsce zaledwie 10 dni po rozpoczęciu nalotów, kiedy NATO przejęło dowodzenie nad siłami koalicyjnymi [Erlanger, Schmitt 2011]. Stany Zjednoczone Ameryki miały odgrywać rolę pomocniczą, wspierając koalicję międzynarodową nie tylko jednostkami sił powietrznych, ale również zapewniając wsparcie wywiadowcze, logistyczne, ratownicze i humanitarne. Za cechę wspólną obydwu doktryn można uznać stosowanie retoryki wolnościowo-demokratycznej, aby usprawiedliwić decyzję o interwencji zbrojnej. Nie tylko G.W. Bush wyzwalał najpierw Afgańczyków, potem Irakijczyków spod rządów tyranów, Obama również stosował podobną argumentację w odniesieniu do Libijczyków. Chociaż warto nadmienić, że bezpośrednim celem operacji nie było wcale obalenie rządów Muammara Kadafiego, tylko ochrona społeczeństwa libijskiego przed „bezpośrednim niebezpieczeństwem”, „powstrzymanie masakry” oraz ustanowienie strefy zakazu lotów. Doprowadzenie do upadku reżimu wymagało, zdaniem Obamy, zaangażowania sił lądowych, a na to nie chciał wydać zgody prezydent, obawiając się powtórki z wieloletniej misji stabilizacyjnej Amerykanów w Iraku [Remarks by the President in Address to the Nation on Libya 2011].

Zestawiając operacje wojskowe w Afganistanie i Iraku z interwencją w Libii, uwidaczniają się zasadnicze różnice w podejściu obydwu prezydentów do realizacji polityki zagranicznej supermocarstwa. Pomimo deklaracji o chęci zaangażowania militarnego szerszej koalicji w Afganistanie G.W. Bush zrezygnował ze wsparcia międzynarodowego z kilku powodów. Po pierwsze, interwencja zbrojna miała 
miejsce niecały miesiąc po zamachach $9 / 11$ i, co za tym idzie, stanowiła niejako manifestację potęgi supermocarstwa. Bush nie chciał dzielić się sukcesem operacji, który, biorąc pod uwagę przewagę technologiczną i militarną Amerykanów nad Talibami, był tylko kwestią czasu. Po drugie, Bush zdawał sobie sprawę, iż udział większej liczby sojuszników spowoduje ograniczenie czy też rozproszenie procesu decyzyjnego. A to Amerykanie mieli odegrać główną rolę w Afganistanie i decydować o przebiegu operacji. W przypadku Iraku sprawa była bardziej skomplikowana, ponieważ operacja nie miała ani legalnych podstaw, ani poparcia społeczności międzynarodowej. W pierwszej fazie operacji (obalenie rządów Saddama Husajna) zabiegano o udział szerszej koalicji, aby usprawiedliwić i uprawomocnić inwazję na Irak. W drugiej fazie (misja stabilizacyjna) administracja Busha chciała podzielić się rosnącymi kosztami operacji z pozostałymi sojusznikami. B. Obama deklarował odmienne podejście do sojuszy i roli USA w systemie międzynarodowym. Chciał mobilizować innych uczestników do działań zbiorowych. Podkreślał, że prawdziwe przywództwo tworzy koalicje i warunki dla współpracy i dzielenia się ciężarem kosztów oraz motywuje innych do przestrzegania zasady sprawiedliwości i praw człowieka [Remarks by the President in Address to the Nation on Libya 2011].

George W. Bush inaczej postrzegał rolę USA w systemie międzynarodowym, sądząc, iż pozycja supermocarstwa daje mu prawo do narzucania woli innym uczestnikom. To Stany Zjednoczone Ameryki miały mieć nadrzędny głos w procesie decyzyjnym. Brak posłuszeństwa interpretowano jako brak lojalności, a nawet działanie na szkodę interesów narodowych USA. Za przykład może posłużyć pesymistyczne nastawienie Niemiec i Francji do planów interwencji zbrojnej w Iraku. Brak zdecydowanego poparcia ze strony dwóch mocarstw europejskich groziło nawet rozłamem wewnętrznym w Unii Europejskiej, zainicjowanym niejako przez USA, a konkretnie Sekretarza Obrony USA - Donalda Rumsfelda, który nazwał Niemcy i Francję „,starą Europą". Podkreślił przy tym rolę nowych członków, oznajmiając przeniesienie „środka ciężkości” na wschód, co miało oznaczać to, że skoro dwa silne mocarstwa europejskie nie chcą współgrać z polityką Waszyngtonu, to Stany Zjednoczone Ameryki zaangażują innych sojuszników. Wypowiedź szefa Departamentu Obrony spotkała się z dużą krytyką, zwłaszcza we Francji i Niemczech, gdzie podkreślano, iż „USA musi nauczyć się, że Unia Europejska jest partnerem, a nie protektoratem” [Hooper, Black 2003].

Chociaż B. Obama podobnie jak G.W. Bush widział USA w roli przywódcy świata, to pełnienie przez supermocarstwo funkcji „policjanta świata” znacznie mniej mu odpowiadało. Ciężar z tym związany obligował Stany Zjednoczone Ameryki do interweniowania wszędzie tam, gdzie dzieje się niesprawiedliwość i są łamane prawa człowieka. Presję z tym związaną prezydent Obama odczuł w momencie użycia broni chemicznej wobec ludności cywilnej w Syrii w sierpniu 2013 r. Pomimo że prezydent USA od początku obarczał winą za te działania reżim Baszszara al-Asada, to jednocześnie $\mathrm{z}$ niechęcią podchodził do interwencji zbrojnej w Syrii, zwłaszcza z wykorzystaniem oddziałów lądowych. Obawiał się ponownego zaangażowania 
Amerykanów w wieloletnią misję stabilizacyjną, która w konsekwencji pociągnęłaby olbrzymie wydatki z budżetu państwa oraz straty w ludności, zwłaszcza po stronie amerykańskiej. Deklaracja Obamy z września 2013 r., kiedy oznajmił, że Ameryka nie jest policjantem świata [Remarks by the President in Address to the Nation on Syria 2013; Waśko-Owsiejczuk 2016a: 165 i n.], wywołała dyskusję o dalszym zaangażowaniu supermocarstwa w rozwiązywanie problemów międzynarodowych. Prezydent USA chciał wykorzystywać środki pokojowe do wywierania nacisku na reżimy. W przeciwieństwie do Busha uważał, że sięgnięcie do siły militarnej jest ostatecznością. W pierwszej kolejności USA miały wykorzystywać dyplomację, negocjacje, ostrzeżenia i sankcje.

Chociaż wyniki sondaży opinii publicznej wskazywały, że większość Amerykanów nie chciała się angażować $\mathrm{w}$ interwencję zbrojną w Syrii1 ${ }^{17}$, to brak zdecydowanej reakcji ze strony B. Obamy zostało ostro skrytykowane nie tylko przez opozycję [Sullivan 2013], lecz także jego byłych współpracowników. Prezydentowi USA zarzucano brak konsekwencji, brak strategii na rozwiązanie kryzysu, straszenie interwencją, „czerwoną linią”, której przekroczenie miała grozić odpowiedź militarna. Brak działań ze strony supermocarstwa na użycie broni chemicznej w Syrii, zdaniem opozycji, było nie tylko oznaką słabości, lecz także zachęcało inne reżimy do wykorzystywania tego typu broni [McElroy 2013; Shanker, D'Avolio 2013; DeYoung 2014]. Nawet była sekretarz stanu w administracji B. Obamy - Hillary Clinton, skrytykowała pasywną postawę prezydenta, wskazując, że doprowadziła do ekspansji dżihadystów w Iraku i Syrii [Frizell 2014].

Podczas drugiej kadencji Baracka Obamy problemy międzynarodowe zaczęły narastać. Prezydent USA musiał się zmierzyć m.in. z coraz bardziej agresywnymi działaniami ze strony „Państwa Islamskiego” [Coll 2014] oraz ekspansywną polityką Rosji na wschodzie Europy [Zięba 2014: 13-40]. Na prośbę rządu irackiego w sierpniu 2014 r. B. Obama wydał decyzję o rozpoczęciu nalotów na pozycje dżihadystów w Iraku [Feeney 2014]. We wrześniu poszerzył kampanię przeciwko ISIS o terytorium Syrii [Roberts, Ackerman 2014; Waśko-Owsiejczuk 2016c: 325 i n.], wykluczając jednocześnie możliwość interwencji sił lądowych. Nowe wyzwania i zagrożenia dla bezpieczeństwa znalazły swój wyraz w Strategii Bezpieczeństwa Narodowego USA z 2015 r. Zasadniczej zmianie uległo podejście do kwestii zacieśniania współpracy z Rosją. Wśród największych zagrożeń dla bezpieczeństwa globalnego, obok rozrastającego się ekstremizmu, cyberterroryzmu, ataków terrorystycznych wymierzonych w infrastrukturę krytyczną, skutków zmian klimatycznych, epidemii chorób zakaźnych, rozprzestrzeniania się broni masowego rażenia, działalności międzynarodowych grup przestępczych, w dokumencie wymieniono agresję Rosji [The National Security Strategy 2015: 1-5].

W nowej strategii B. Obama podkreślił, że USA są bardziej skuteczne, kiedy działają w ramach międzynarodowych koalicji, przestrzegają prawa, postępują zgod-

\footnotetext{
${ }^{17} 68 \%$ respondentów opowiedziało się przeciwko amerykańskiej interwencji w Syrii [Jones 2013].
} 
nie $\mathrm{z}$ amerykańskimi wartościami, sprzeciwiają się torturom i przemocy. Prezydent USA, podtrzymując zobowiązania wobec sojuszników, zaznaczył jednocześnie, że amerykańskie wpływy i zasoby nie są ograniczone i, co za tym idzie, Amerykanie często muszą wybierać pomiędzy konkurującymi ze sobą priorytetami. Główne założenie doktryny B. Obamy w postaci strategicznej cierpliwości i wytrwałości zostało utrzymane. Podobnie w przypadku wykorzystywania środków pokojowych do rozwiązywania sporów międzynarodowych, zwalczania zagrożeń i wyzwań dla bezpieczeństwa. Głównym narzędziem polityki zagranicznej USA nadal miała być dyplomacja. Zdaniem prezydenta USA, mądra strategia bezpieczeństwa narodowego nie może się opierać wyłącznie na sile militarnej. Za bardziej skuteczną uznał długoterminową współpracę pomiędzy państwami w celu przeciwdziałania rozprzestrzenianiu się ideologii ekstremistów i eliminacji przyczyn oraz korzeni od uśmiercania terrorystów. Stany Zjednoczone Ameryki nadal miały pełnić rolę przywódcy świata, zjednując i mobilizując innych uczestników stosunków międzynarodowych do działania przez przykładne stosowanie się do prawa, reguł i wartości uniwersalnych (amerykańskich). W dokumencie podkreślono istotę rewolucji energetycznej w USA, dzięki której supermocarstwo znalazło się na czele listy największych na świecie producentów gazu ziemnego i ropy naftowej, co znacznie uniezależniło Amerykanów od dostawców zewnętrznych [The National Security Strategy 2015: 1-5].

Warto podkreślić, iż poza pewnymi elementami wspólnymi NSS z 2015 r. zasadniczo różni się od tej z 2010 r., gdyż zmieniono proporcje deklarowanego użycia i wagi poszczególnych instrumentów, zwłaszcza dyplomacji i sankcji ekonomicznych, które w strategii z 2015 r. miały kluczowe znaczenie w relacjach z Rosją. Priorytetem NSS z 2015 r. była ochrona i zapewnienie bezpieczeństwa krajowego (w obrębie granic amerykańskich), tym samym nie była to strategia globalna.

Nowa strategia bezpieczeństwa USA nie została pozytywnie oceniona, zwłaszcza w szeregach Republikanów. Obamie zarzucano pasywność w polityce zagranicznej, brak zdecydowanej reakcji na rosnące zagrożenie ze strony „Państwa Islamskiego” i Rosji [Obama security agenda urges 'strategic patience,' drawing criticism amid ISIS threat 2015; Roth 2015], nieudolność i pochopność w podejmowaniu decyzji - jak chociażby zbyt wczesne wycofanie amerykańskich oddziałów wojskowych z Iraku, co wpłynęło na destabilizację kraju i nasilenie terroryzmu [O'Hanlon 2015]. Nawet w szeregach Demokratów doktrynę B. Obamy oceniano jako zbyt ostrożną [Hicks 2014]. Byli współpracownicy prezydenta podkreślali ponadto, że on sam „nie wierzył w powodzenie własnej strategii, nie uważał, że jest to jego wojna”, a za najważniejszy cel polityki zagranicznej obrał wycofanie Amerykanów z Iraku i Afganistanu [Woodward 2014]. Zbyt ostrożne i upolitycznione działania B. Obamy, ich zdaniem, doprowadziły do osłabienia wpływów USA za granicą [Nasr 2013]. Krytycy wskazywali, iż prezydent przywiązywał zbyt wiele uwagi innym mniej pilnym problemom, jak np. zmianom klimatycznym, pozostawiając Irak na pastwę radykalnych islamskich grup terrorystycznych. Pasywna postawa prezydenta doprowadziła, ich zdaniem, do destabilizacji Iraku, który w 2009 r. był oczyszczony 
z terrorystów. Podkreślano, że nowy prezydent powinien był wynegocjować z rządem irackim pozostawienie kilku oddziałów wojsk amerykańskich w Iraku, którzy utrzymaliby bezpieczeństwo w regionie [Cheney 2014; Ramirez 2014]. Obrońcy doktryny B. Obamy wskazywali, że podejmując decyzję o wycofaniu wojsk, prezydent realizował wolę obywateli, którzy zdecydowanie opowiadali się za powrotem wszystkich jednostek do USA ${ }^{18}$. Podkreślano, że ostrożna polityka prezydenta jest podyktowana nastrojami społeczeństwa, które bardziej preferuje negocjacje i wykorzystywanie soft power od konfrontacji militarnej. Argumenty te nie trafiały do krytyków postawy B. Obamy, którzy zarzucali mu brak przywództwa, wskazując, że prezydent supermocarstwa powinien rządzić i prowadzić solidną oraz zdecydowaną politykę zagraniczną USA, a nie podążać za opinią publiczną [Crowley 2014].

Kiedy w 2009 r. Barack Obama przejmował władzę w Białym Domu, jego poprzednik był oceniany jako jeden z najgorszych prezydentów USA [Saad 2009]. W połowie drugiej kadencji B. Obama w rankingach na najgorszego prezydenta Stanów Zjednoczonych Ameryki po II wojnie światowej wyprzedził samego George'a W. Busha. Blisko połowa Amerykanów wskazała, że byłoby korzystniej, gdyby w wyborach w 2012 r. zwyciężył kandydat Republikanów - Mitt Romney, który lepiej poradziłby sobie w roli przywódcy supermocarstwa. Dezaprobatę dla realizacji polityki zagranicznej przez 44. prezydenta USA wyraziło $40 \%$ respondentów, a ponad $50 \%$ wytknęło administracji B. Obamy niekompetencję [Boyer, Dinan 2014]. Ostatecznie B. Obama zakończył drugą kadencję z niższym poparciem od G.W. Busha [Jones 2017].

\section{ZAKOŃCZENIE}

Amerykańską kampanię wyborczą w 2008 r. zdominowały dwie kwestie - polityka zagraniczna i rosnący deficyt budżetowy. Zmęczeni dwiema wojnami Amerykanie oczekiwali od nowego prezydenta skupienia się na sprawach wewnętrznych. Zapowiedź całkowitego odwrotu od polityki George'a W. Busha okazała się skuteczną taktyką, umożliwiającą Barackowi Obamie wygranie wyborów. Od tej pory supermocarstwo zamiast siły militarnej miało wykorzystywać dialog i dyplomację. Odnowienie wizerunku USA na świecie wymagało od Obamy odejścia od polityki zagranicznej opartej na hard power, samodzielnych, prewencyjnych i jednostronnych działaniach na rzecz bliskiej współpracy z innymi uczestnikami stosunków międzynarodowych. Przez dwie kadencje Barack Obama realizował politykę, która wydawała się być zgodna z oczekiwaniami Amerykanów. Nie spełnił wszystkich obietnic wyborczych, takich jak chociażby zamknięcie więzienia w Guantanamo, ale sprowadził amerykańskich żołnierzy do domu, naprawił relacje międzynarodowe i nie dopuścił do zaangażowania sił lądowych USA w kolejne operacje zbrojne.

${ }^{18}$ Ponad 70\% ankietowanych opowiedziało się za wycofaniem wszystkich oddziałów amerykańskich z Iraku [Jones 2011]. 
Doktryna B. Obamy jest oceniania różnie, jedni nazywają ją zbyt ostrożną, inni wyważoną. Co ciekawe, sami Amerykanie, którzy wybrali nowego prezydenta w celu naprawy szkód wyrządzonych przez administrację G.W. Busha, ocenili Obamę gorzej niż poprzednika [Boyer, Dinan 2014]. Autorka niniejszego artykułu przychyla się do tezy z książki Martina Indyka, Kennetha Lieberthala, Michaela O’Hanlona, iż politykę zagraniczną B. Obamy można określić bardziej jako pragmatyczną niż wizjonerską [Indyk, Lieberthal, O’Hanlon 2013: 231]. Nawet jeżeli w trakcie trwania kadencji Amerykanie zmienili zdanie, oczekując bardziej zdecydowanych działań ze strony prezydenta w zakresie polityki zagranicznej ${ }^{19}$, to w 2008 r. wybrali Baracka Obamę na prezydenta Stanów Zjednoczonych Ameryki po to, aby zmienił wizerunek supermocarstwa z „,bandyckiej potęgi” na „łagodnego hegemona”. To zadanie można uznać za zrealizowane.

\section{BIBLIOGRAFIA}

Adams, R., David, B. 2011. Libya resolution: UN security council air strikes vote - as it happened. "The Guardian" 17.03 .

Applebaum, A. 2009. The Russia Reset Button Doesn't Work. "The Washington Post" 24.03.

Baker, P. 2009. White House Scraps Bush's Approach to Missile Shield. "International New York Times" 17.09. Boyer, D., Dinan, S. 2014. Hands down, Obama is the worst president since WWII: poll. "The Washington Times" 02.07.

Burns, R. 2005. Pentagon Used White Phosphorous in Iraq. "The Washington Post" 16.11.

Cheney, D., Cheney, L. 2014. The Collapsing Obama Doctrine. "The Wall Street Journal” 17.06.

Coll, S. 2014. In Search of a Strategy. "The New Yorker” 08.09.

Creamer, R. 2014. Bush/Cheney Created Conditions That Led Directly to ISIL. „Huffington Post” 15.09, http://www.huffingtonpost.com/robert-creamer/bushcheney-created-condit_b_5820916.html (dostęp: 05.03.2016).

Crowley, M. 2014. This May Be the Real Obama Doctrine. "The Time" 28.05.

Defense Planning Guidance. 1992. Raport dostępny jest na stronie: National Security Archive, http:// nsarchive.gwu.edu/nukevault/ebb245/ (dostęp: 03.03.2016).

DeYoung, K. 2014. Senators unleash criticism of Obama administration over handling of war in Syria. "The Washington Post" 26.03.

Dziekan, M. 2014. W Iraku z demokracja kojarzy się chaos i śmierć. „Gazeta Pomorska” 05.07.

Erlanger, S., Schmitt, E. 2011. NATO Set to Take Full Command of Libyan Campaign. "International New York Times" 25.03.

Erlanger, S., Stolberg, S. 2009. Surprise Nobel for Obama Stirs Praise and Doubts. "International New York Times" 09.10.

Feeney, N. 2014. Obama Authorizes Air Strikes in Iraq to Help Retake Dam. "The Time” 17.08.

Frizell, S. 2014. Hillary Clinton Criticizes Obama on Syria Policy. "The Time" 10.08.

Garrison, J. 2005. Ameryka jako imperium. Przywódca świata czy bandycka potęga?, Von Borowiecky, Warszawa.

\footnotetext{
${ }^{19}$ Większość Amerykanów szczególnie krytycznie odnosiła się do polityki zwalczania terroryzmu w wydaniu B. Obamy. Zob. President Obama approval ratings, the economy and ISIS. 2015, „The Washington Post" 05.06.
} 
Gasztold, A. 2017. Strategie antyterrorystyczne USA i RFN po 11 września 2001 r. „Kwartalnik Naukowy OAP e-Politikon", nr 21.

Hersh, S.M. 2004. Torture at Abu Ghraib. "The New Yorker" 10.05.

Hicks, J. 2014. Obama foreign policy sparks bipartisan criticism. "The Washington Post" 21.08.

Hooper, J., Black, I. 2003. Anger at Rumsfeld attack on 'old Europe'. "The Guardian" 24.01.

Iiikoff, M. 2009. Obama's Order Ends Bush-Era Interrogation Tactics. "Newsweek" 21.01.

Jones, J.M. 2011. Three in Four Americans Back Obama on Iraq Withdrawal. Gallup, http://www.gallup. com/poll/150497/three-four-americans-back-obama-iraq-withdrawal.aspx (dostęp: 17.03.2016).

Jones, J.M. 2013. Americans Oppose U.S. Military Involvement in Syria. Gallup, http://www.gallup.com/ poll/162854/americans-oppose-military-involvement-syria.aspx (dostęp: 16.03.2016).

Jones, J.M. 2017. Obama Averages 47.9\% Job Approval as President. Gallup, http://www.gallup.com/ poll/202742/obama-averages-job-approval-president.aspx (dostęp: 06.09.2017).

Lizza, R. 2008. Battle Plans. How Obama won. "The New Yorker" 17.11.

Londoño, E. 2013. Study: Iraq, Afghan war costs to top \$4 trillion. "The Washington Post" 28.03.

Marschall, C. 2008. Barack Obama czarnoskóry Kennedy, Studio Emka, Warszawa.

McElroy, D. 2013. Criticism grows as Barack Obama welcomes Syria deal as 'important Step'. "The Telegraph" 15.09.

Memorandum to Congress on President Bush's Order Establishing Military Tribunals. 2002. „American Civil Liberties Union", www.aclu.org/technology-and-liberty/memorandum-congress-president-bushs-order-establishing-military-tribunals (dostęp: 06.03.2016).

Miller, L.B. 2014. The United States and the Arab spring. Now and then in the Middle East, [w:] I. Parmar, L.B. Miller, M. Ledwidge (red.), Obama and the World. New Directions in US Foreign Policy, Routledge, New York.

Millions join global anti-war protests. 2003. „BBC News”, http://news.bbc.co.uk/2/hi/europe/2765215. stm (dostęp: 04.03.2016).

Modrzejewska-Leśniewska, J. 2010. Afganistan, TRIO, Warszawa.

Myers, S.L. 2008. Bush Decides to Keep Guantánamo Open. "International New York Times" 20.10.

Nasr, V. 2013. The Dispensable Nation: American Foreign Policy in Retreat, Anchor, New York.

Nye, J.S. 2007. Soft Power. Jak osiagnać sukces w polityce światowej, Wydawnictwa Akademickie i Profesjonalne, Warszawa.

Obama security agenda urges 'strategic patience, 'drawing criticism amid ISIS threat. 2015. „Fox News”, http://www.foxnews.com/politics/2015/02/07/obama-security-agenda-urges-strategic-patience-drawing-criticism/ (dostęp: 17.03.2016).

O'Hanlon, M.E. 2015. Feckless and Timid? Or Shrewd and Skillful? Obama's Foreign Policy Assessed. „Newsweek”25.05.

President Bush and Iraq Prime Minister Maliki Sign the Strategic Framework Agreement and Security Agreement. 2008. Office of the Press Secretary, http://georgewbush-whitehouse.archives.gov/news/ releases/2008/12/20081214-2.html (dostęp: 05.03.2016).

President Obama approval ratings, the economy and ISIS. 2015. „The Washington Post” 05.06.

President Signs Authorization for Use of Military Force bill. 2001. Office of the Press Secretary, http:// georgewbushwhitehouse.archives.gov/news/releases/2001/09/20010918-10.html (dostęp: 02.03.2016).

Ramirez, L. 2014. Critics Question Obama Doctrine. „Voice of America”, http://www.voanews.com/ content/critics-question-obama-doctrine/1915693.html (dostęp: 17.03.2016).

Remarks by the President in Address to the Nation on Libya. 2011. White House, https://www.whitehouse. gov/the-press-office/2011/03/28/remarks-president-address-nation-libya (dostęp: 15.03.2016).

Remarks by the President in Address to the Nation on Syria. 2013. White House, www.whitehouse.gov/ the-press-office/2013/09/10/remarks-president-address-nation-syria (dostęp: 16.03.2016).

Roach, K. 2011. The 9/11 Effect: Comparative Counter-Terrorism, Cambridge University Press, New York. Roberts, D., Ackerman, S. 2014. Barack Obama authorises air strikes against Isis militants in Syria. "The Guardian" 11.09. 
Roth, S. 2015. Rand Paul On Obama’s Foreign Policy: 'What Kind Of Idiot Sends Four People To War. „Huffpost Politics", http://www.huffingtonpost.com/entry/rand-paul-obamas-foreign-policy_56451fe7e4b045bf3dee865a (dostęp: 17.03.2016).

Saad, L. 2009. Americans Expect History to Judge Bush Worse Than Nixon. Gallup, http://www.gallup. com/poll/113806/americans-expect-history-judge-bush-worse-than-nixon.aspx (dostęp: 18.03.2016).

Separation Of Powers And Checks And Balances. Cornell Law School, www.law.cornell.edu/anncon/html/ art1frag1_user.html (dostęp: 06.03.2016).

Shanker, T., D’Avolio, L. 2013. Former Defense Secretaries Criticize Obama on Syria. "International New York Times" 18.09.

Statement by His Excellency Mr. George W. Bush, President of the United States of America Address to the United Nations General Assembly. 2003, http://www.un.org/webcast/ga/58/statements/usaeng030923. htm (dostęp: 05.03.2016).

Status of Forces Agreement: Agreement Between the United States of America and Republic of Iraq on the Withdrawal of United States Forces from Iraq and the Organization of Their Activities during Their Temporary Presence in Iraq. 2008, http://www.state.gov/documents/organization/122074.pdf (dostęp: 04.03.2016).

Sullivan, S. 2013. Republicans criticize Obama on Syria. "The Washington Post" 16.06.

Szymborski, W. 2004. Doktryna Busha, Wers, Bydgoszcz.

Tanner, S. 2007. Wojny Bushów. Ojciec i syn jako zwierzchnicy sił zbrojnych, Wydawnictwo Dolnośląskie, Wrocław.

The National Security Strategy of the United States of America. 2002. White House, http://www.state.gov/ documents/organization/63562.pdf (dostęp: 03.03.2016).

The National Security Strategy of The United States of America. 2006. White House, http://georgewbush -whitehouse.archives.gov/nsc/nss/2006/ (dostęp: 04.03.2016).

The National Security Strategy. 2010. White House, https://www.whitehouse.gov/sites/default/files/rss_viewer/national_security_strategy.pdf(dostęp: 06.03.2016).

The National Security Strategy. 2015. White House, http://nssarchive.us/wp-content/uploads/2015/02/2015. pdf (dostęp: 17.03.2016).

Tyler, P.E. 1992. U. S. Strategy Plan Calls for Insuring No Rivals Develop a One-Superpower World. „,The New York Times" 08.03.

Vaïsse, J. 2010. Why Neoconservatism Still Matters. "Policy Paper”, No. 20.

Waśko-Owsiejczuk, E. 2014. Polityka bezpieczeństwa narodowego Stanów Zjednoczonych Ameryki w latach 2001-2009, Avalon, Kraków.

Waśko-Owsiejczuk, E. 2015. Polityka administracji George'a W. Busha wobec Bliskiego Wschodu-o planach demokratyzacji i stabilizacji gospodarczej regionu. „Przegląd Politologiczny”, nr 2.

Waśko-Owsiejczuk, E. 2016a. Geostrategia Stanów Zjednoczonych w dobie „, rewolucji łupkowej”. „Studia Polityczne", nr 1 (41).

Waśko-Owsiejczuk, E. 2016b. Globalizacja tortur-o programie tajnych więzień CIA na świecie. „Politeja. Pismo Wydziału Studiów Międzynarodowych i Politycznych Uniwersytetu Jagiellońskiego”, nr 45.

Waśko-Owsiejczuk, E. 2016c. The American Military Strategy to Combat the 'Islamic State' in Iraq and Syria: Assumptions, Tactics and Effectiveness. "Polish Political Science Yearbook", Vol. 45.

Waśko-Owsiejczuk, E. 2017. Wpływ polityki USA na powstanie „państwa” islamskiego. O spuściźnie prezydentury George'a W. Busha. „Athenaeum. Polskie Studia Politologiczne”, Vol. 53.

Włodkowska, A. 2010. Wykorzystanie hard i soft power przez Federację Rosyjska i Unię Europejską w regionie czarnomorskim, [w:] T. Kapuśniak (red.), Unia Europejska i Federacja Rosyjska wobec regionu Morza Czarnego. „Studia Wschodnie”, Instytut Europy Środkowo-Wschodniej, Lublin.

Włodkowska-Bagan, A. 2012. Soft Power w polityce zagranicznej Federacji Rosyjskiej wobec państw „, bliskiej zagranicy”. „Kwartalnik Naukowy OAP UW e-Politikon”, nr 3.

Woodward, B. 2014. Robert Gates, former defense secretary, offers harsh critique of Obama's leadership in 'Duty'. "The Washington Post" 07.01. 
Zaborowski, M. 2013. Obama - pragmatyczny idealista. Wstęp do wydania polskiego, [w:] M.S. Indyk, K.G. Lieberthal, M.E. O’Hanlon (red.), Zmieniając historię. Polityka zagraniczna Baracka Obamy, PISM, Warszawa.

Zając, J. 2008. Koncepcja bezpieczeństwa USA, [w:] R. Zięba (red.), Bezpieczeństwo międzynarodowe po zimnej wojnie, Wydawnictwa Akademickie i Profesjonalne, Warszawa.

Zięba, R. 2014. Międzynarodowe implikacje kryzysu ukraińskiego. „Stosunki Międzynarodowe”, nr 2, t. 50.

\section{HARD POWER VERSUS SOFT POWER - A CHANGE OF US FOREIGN POLICY FROM OFFENSIVE TO DEFENSIVE UNDER THE LEADERSHIP OF BARACK OBAMA}

Abstract: The presidential election campaign in 2008 was dominated by two issues - foreign policy and the growing budget deficit. Barack Obama's announcement of a complete reversal of the aggressive policy of his predecessor proved to be an effective tactic, allowing him to win the presidential election. From this point on, instead of military force, the superpower was to use dialogue and diplomacy. Renewal of the US image in the world required from Obama the ending of foreign policy based on hard power, preventive and unilateral action, in favor of close cooperation with other participants in international relations.

Keywords: security, foreign policy, United States of America, Barack Obama, George W. Bush

\section{BIOGRAM}

Ewelina Waśko-Owsiejczuk, dr, adiunkt w Instytucie Historii i Nauk Politycznych Uniwersytetu w Białymstoku, którego jest absolwentką. Ukończyła również Wydział Dziennikarstwa i Nauk Politycznych Uniwersytetu Warszawskiego (magister politologii, doktor nauk humanistycznych w zakresie nauk o polityce). Stypendystka Roosevelt Study Center w Middelburgu (2016 r.) oraz John F. Kennedy Institute for North American Studies przy Freie Universität w Berlinie (2017 r.). Prezes Zarządu Oddziału Polskiego Towarzystwa Nauk Politycznych - Oddział w Białymstoku. Prowadzi badania m.in. nad polityką bezpieczeństwa USA, skupiając się na problematyce zwalczania terroryzmu, transformacji Wspólnoty Wywiadowczej Stanów Zjednoczonych po $2001 \mathrm{r}$. oraz nad polityką zagraniczną USA wobec Bliskiego Wschodu. Autorka monografii Polityka bezpieczeństwa narodowego Stanów Zjednoczonych Ameryki w latach 2001-2009, Kraków 2014, ss. 330; oraz artykułów, m.in. National Security Letters - A Controversial FBI Tool to Fight Terrorism, „Internal Security” 2015, Vol. 7 (2), pp. 71-90; The American Military Strategy to Combat the 'Islamic State' in Iraq and Syria: Assumptions, Tactics and Effectiveness, „Polish Political Science Yearbook” 2016, Vol. 45, pp. 317-336; ,, Geostrategia Stanów Zjednoczonych w dobie "rewolucji tupkowej«”, „Studia Polityczne” 2016, nr 1 (41), s. 153-176; Globalizacja tortur - o programie tajnych więzień CIA na świecie, „Politeja. Pismo Wydziału Studiów Międzynarodowych i Politycznych Uniwersytetu Jagiellońskiego" 2016, nr 45, s. 207-233. Kontakt e-mail: wasko-owsiejczuk@uwb.edu.pl. 